\title{
Blind Versus Ultrasound Guidance Injections: Lateral Femoral Cutaneous Nerve Blockage Revisited
}

\author{
Lateral Femoral Kutanöz Sinirinin Kör ve Ultrason Eşliğinde Yapılan \\ Blokajının Değerlendirilmesi
}

\begin{abstract}
Berke Aras ${ }^{1}$, (1) Emre Adıgüzel2 ${ }^{2}$, (1) Fatih Tok ${ }^{2}$
${ }^{1}$ Kastamonu Rehabilitation Centre, Department of Physical Medicine and Rehabilitation, Kastamonu, Turkey

2University of Health Sciences, Gaziler PM\&R Research and Training Hospital, Department of Physical Medicine and Rehabilitation, Ankara, Turkey

Abstract

Meralgia paresthetica is a nerve entrapment that may cause pain, numbness, hypersensivity, and paresthesias within the anterolateral region of the thigh, which is the area of distribution of the lateral femoral cutaneous nerve (LCFN). According to the literature, there is a large variability in the nerve course as the nerve pierces the inguinal ligament. Blockade of the LFCN has been classically described using anatomic landmarks, but the anatomic variability of the nerve may be responsible for failure rates being as high as 60\%. Ultrasound (US) guidance for peripheral nerve blocks has become popular among physicians because of its several advantages when compared with traditional nerve localization techniques. US-guided LCFN blocks can be performed with better success.
\end{abstract}

Keywords: Meralgia paresthetica, ultrasound-guided injection, lateral femoral cutaneus nerve

\section{$\ddot{O} z$}

Meraljia parestetika, lateral femoral kutanöz sinirin (LFKN) dă̆ılım alanı olan uyluk ön-dış bölümünde ağrı, hissizlik, hipersensivite ve parestezilere yol açan bir tuzak nöropatisidir. Literatüre göre, sinirin inguinal ligament geçtiği sinir trasesinde fazla miktarda varyasyon görülmektedir. LFKN blokajı klasik olarak anatomik noktalar kullanılarak uygulanır fakat anatomik variabilitenin olması enjeksiyonunun başarı yüzdesini \%60 gibi yüksek bir oranda etkilemektedir. Ultrason (US) eşliğinde periferik sinir blokajı, geleneksel sinir lokalizasyon teknikleri ile mukayese edildiğinde birçok avantajı olması sebebiyle birçok klinisyen arasında popüler olmuştur. US eşliğinde yapılan LFKN blokları daha başarılı sonuçlar vermektedir.

Anahtar Kelimeler: Meraljia parestetika, ultrason eşliğinde enjeksiyon, lateral femoral kutanöz sinir

\section{Introduction}

Meralgia paresthetica (MP) is a nerve entrapment that may cause pain, numbness, hypersensitivity, and paresthesia within the anterolateral region of the thigh, which is the lateral femoral cutaneous nerve (LFCN) distribution area (1). The incidence rate of $\mathrm{MP}$ is $4.3 / 10,000$ patient years in the general population and $24.7 / 10,000$ patient years in individuals with diabetes mellitus $(2,3)$. It is seen commonly in obese patients and pregnant women due to abdominal bulging over the inguinal ligament, but it can be caused by tight clothing, direct trauma, muscle spasm, seat belts, pelvic tumors, scoliosis, and metabolic (diabetes mellitus) and iatrogenic (hip joint replacement and spine surgery) conditions.

The LFCN is a pure sensory nerve that originates from the L2 and L3 spinal nerve roots, travels downward lateral to the psoas muscle, and passes the iliacus muscle diagonally towards the anterior superior iliac spine (ASIS). It travels along the posterior wall of the pelvis until it exits the pelvis and enters the femoral region. Near the ASIS, the nerve courses in contact with the lateral side of the inguinal ligament. Below the inguinal ligament, the nerve divides into anterior and posterior branches; the anterior branch controls the frontal femoral region up to the knee area, and the posterior branch controls the lateral femoral region up to the greater trochanter area. The terminal branches of the nerve are not visible on ultrasound (US).

This anatomic course has been accepted by physicians, but according to the literature, there is a large variability in the nerve course as the nerve pierces the inguinal ligament. This variability causes reduced success of blind injections and an increased potential risk for iatrogenic injury during groin surgery such as iliac crest bone grefting, hernia repair, and angiography (4).

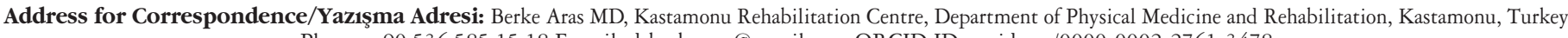
Phone: +90 5365851518 E-mail: drberkearas@gmail.com ORCID ID: orcid.org/0000-0002-2761-3478

Received/Geliş Tarihi: 23.06.2018 Accepted/Kabul Tarihi: 07.01.2019

${ }^{\circ}$ Copyright 2019 by Turkish Neurological Society

Turkish Journal of Neurology published by Galenos Publishing House. 
Anatomy studies showed that the distance from the LFCN to the ASIS at the inguinal ligament can range from $3 \mathrm{~mm}$ to $7.3 \mathrm{~cm}$ $(5,6,7)$. Hospodar et al. (5) reported that the course of the nerve was commonly found 10 to $15 \mathrm{~mm}$ from the ASIS; however, it was found as far medially as $46 \mathrm{~mm}$. In addition, LFCN lateral to the ASIS has also been reported (8). For these reasons, there have been many methods suggested for LFCN block.

Blockage of the LFCN has been classically described using anatomic landmarks, but the anatomic variability of the nerve may be responsible for failure rates being as high as 60\%. Nerve stimulation techniques increase the success rate up to $85 \%$, but their use is limited due to the time needed, patient discomfort, and technique, which depends on the patient's subjective symptoms of paresthetica (9).

Identification of the LFCN location as it enters the anterior thigh is very critical for a successful nerve block. In the blind technique, the ASIS and inguinal ligament are important landmarks. The ASIS can be easily palpated in most patients and the inguinal ligament runs between this bony protuberance and the pubic symphysis. The common technique of physicians is to perform an injection $1 \mathrm{~cm}$ medial to the ASIS and immediately inferior to the ligament (10).

Blind techniques mostly fail in patients with obesity. Sometimes accurate localization of the topographic landmarks is quite difficult because of an inferiorly hanging abdominal pannus. The abdominal pannus should be retracted superiorly to palpate the appropriate landmarks.

US is increasingly used for peripheral nerve block and it has been shown to be particularly suitable for observation and injection of small and superficial structures such as the LFCN (8). US guidance for peripheral nerve blocks has become popular among physicians because of several advantages when compared with traditional nerve localization techniques (anatomic landmarks and peripheral nerve stimulation). US guidance allows for realtime direct visualization of a target nerve, the nearby anatomic structures, the volume distribution of the local anesthetic, and also avoids complications such as the inadvertent puncture of vessels. In this regard, color Doppler US can help to differentiate vascular structures from soft tissues and peripheral nerves. Providing close proximity to the nerve, US guidance may also change the clinical practice of nerve blocks, that is, reducing the time of onset and decreasing the amount of local anesthetics to be used, thereby potentially reducing their adverse events without decreasing the effectiveness of analgesia. In addition, the possible detection of anatomic variations during imaging can also increase the success rate and safety of LFCN block (11).

Profound knowledge of anatomic and some technical aspects are mandatory for US-guided injections. Practically, US-guided LFCN blocks can be performed in two ways: indirectly and directly. In the former method, the nerve is first scanned with US. Then, the place/depth of the injection point is determined and marked on the skin. Thereafter, the injection is performed after the probe is taken away. This method overcomes the necessity of sterile gel for the probe and also provides convenience if another person is going to perform the injection. However, this method has some concerns. First, the LFCN is very thin, and the depth of the nerve may change even with mild differences of probe compression or if the patient somehow contracts the muscle during the injection.
Second, it could be difficult to ascertain the exact length of the needle being inserted because needles have no markers on them (12).

The second method can, in turn, be performed in two ways according to the visualization of the needle for out-plane (transverse approach) (Figure 1). To initiate the injection with a test dose (usually saline) and to observe its spread in the tissue can be useful to ensure the correct depth of the needle. This technique provides easy determination for the correct needle position, and also before injecting the remaining dose, the practitioner can readjust the needle position in order to find the target area. During the injection, the injectate, which is spreading out around the nerve tissue, usually forms a view like an echogenic cloud (Figure 2) (13).

$\mathrm{Ng}$ et al. (14) investigated the accuracy of US compared with anatomic landmarks $(2.5 \mathrm{~cm}$ interior and $2.5 \mathrm{~cm}$ below the ASIS) in identifying the LFCN in human cadavers and volunteers. A needle was inserted targeting the LFCN with US guidance and green dye was injected. A second needle was inserted using anatomic landmarks. The LFCN was identified by dissection, and coloring of the LFCN and needle positioning were evaluated. Location accuracy using anatomic landmarks was $5.3 \%$ in cadavers and $0 \%$ in volunteers, whereas accuracy with US guidance was $84.2 \%$ in cadavers and $80 \%$ in volunteers.

Hurdle et al. (15) investigated the accuracy of US guidance for identifying the LFCN and reported a $100 \%$ success rate in US-guided blockage of the nerve in 10 patients with a small local anesthetic dose of $1 \mathrm{~mL}$ to $8 \mathrm{~mL}$. The amount of local anesthetics used in blockage was reduced in US guidance when

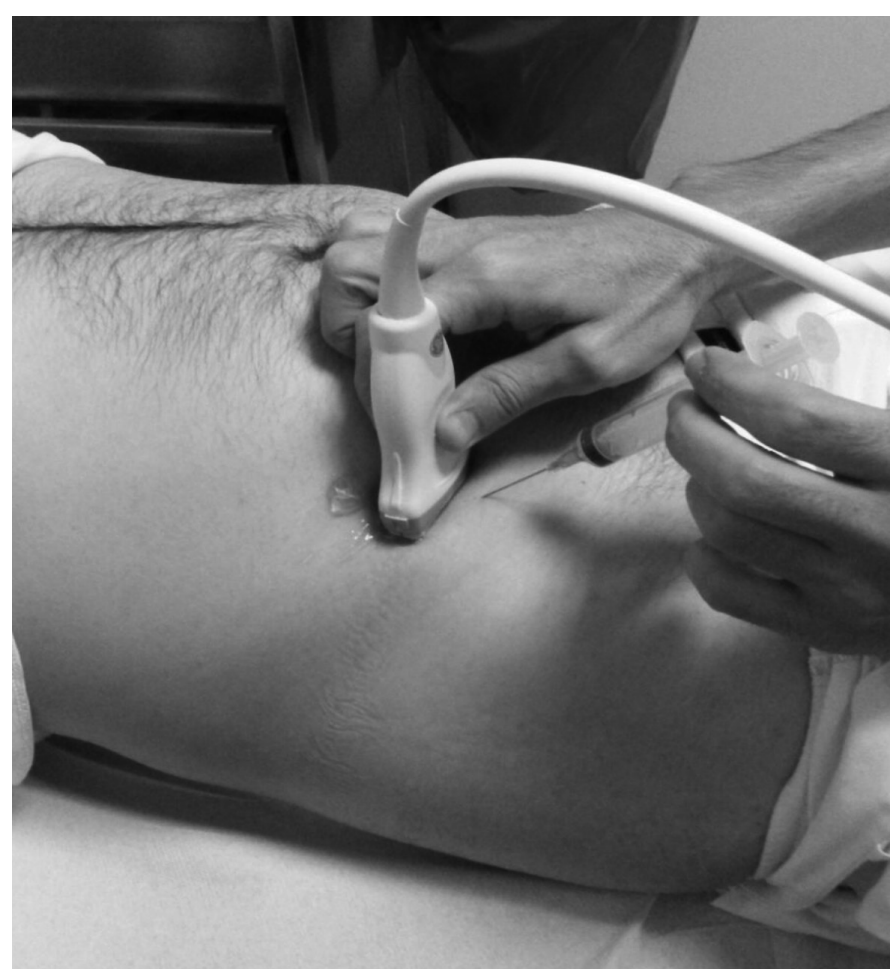

Figure 1. Positioning of the transducer and the injection needle during direct method in lateral femoral cutaneous nerve blockage for out-plane technique (transverse approach). 


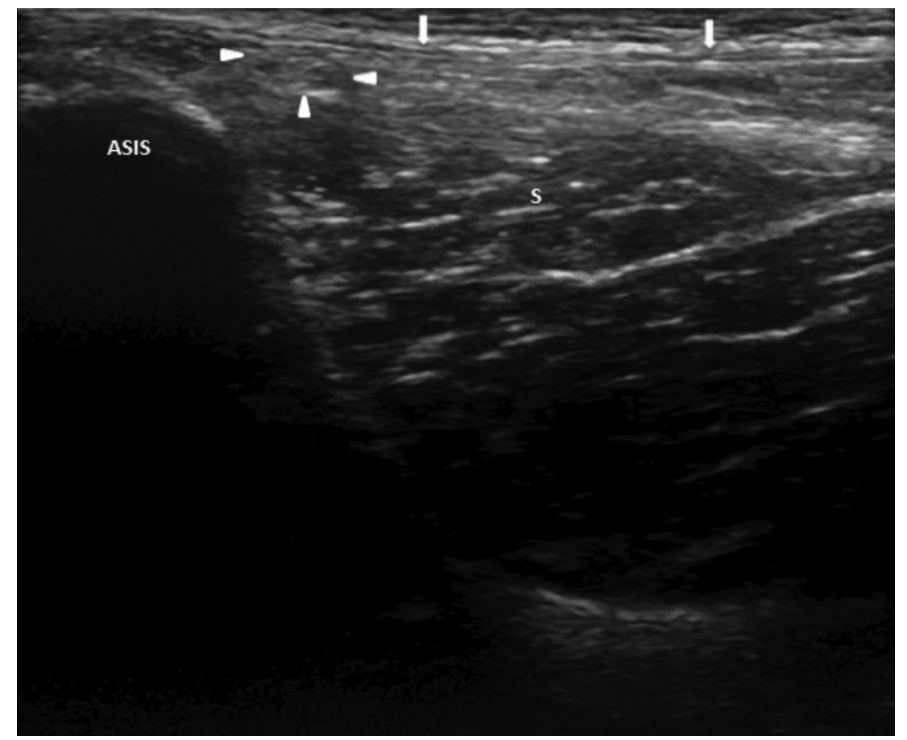

Figure 2. Ultrasound image shows the axial view of the lateral femoral cutaneous nerve beneath the inguinal ligament and medially located to the anterior superior iliac spine. Arrowheads, lateral femoral cutaneous nerve; arrows, inguinal ligament; S, Sartorius muscle; anterior superior iliac spine, anterior superior iliac spine.

ASIS: Anterior superior iliac spine

compared with blind techniques. In blind blocks, the amount of local anesthetic required was not less than $30 \mathrm{~mL}$ (16). Reducing the amount of local anesthetic agent can reduce complications such as unintended blockage of the femoral or obturator nerve (16).

Bodner et al. (4) investigated the feasibility of US guidance for visualizing the LFCN in a cadaver and 8 volunteers. USguided dye injection was performed in 1 cadaver and US-guided anesthetic blockage of the LFCN was performed in volunteers. The LFCN was identified in the cadaveric specimen on both sides and in all but one volunteer. The mean distance of the LFCN from the ASIS was $2.9 \mathrm{~cm}$ on the right side and $2.8 \mathrm{~cm}$ on the left side. The mean duration of the blockage was 4.4 hours with $0.3 \mathrm{~mL}$ with local anesthetics. LFCN blockage with local anesthetics can also be used for harvesting split-thickness skin grafts in burn wounds. Generally, split thickness autografts are harvested from the lateral thigh area, which is innervated by the LFCN. Shteynberg et al. (17) demonstrated that US-guided blockage of the LFCN provided a simple and safe technique to achieve anesthesia for harvesting skin from the lateral thigh. Wardrop and Nishikawa (18) suggested that the mean area anesthetized after LFCN was $569 \mathrm{~cm}^{2}$, which is certainly adequate for providing a large graft.

Although the results of comperative studies (blind vs USguided) as regards treatment outcomes might be considered as variable, there is no discussion on the better targeting of tissues/ pathologies. As with all nerve blocks, the target of these injection techniques is the area of the nerve, not into the perineural space. Penetration should be avoided because of the risk of including neuropraxia. Moreover, apart from the discussion regarding the comparison of blind and US-guided techniques, during our interventional physiatrist practice, we have noticed that US imaging also makes a significant contribution at the decisionmaking step of LFCN injection (19).

To conclude, we strongly argue that the use of blind injections has become debatable for LFCN blockage. The potential complications of LFCN blockage such as nerve puncture, intraneural injection, unintentional motor blocks of femoral and obturator nerve involvement, and intravascular injections could be avoided with US guidance.

\section{Ethics}

Peer-review: Internally peer-reviewed.

\section{Authorship Contributions}

Concept: B.A., E.A., F.T., Design: B.A., E.A., F.T., Data Collection or Processing: B.A., E.A., F.T., Analysis or Interpretation: B.A., E.A., F.T., Literature Search: B.A., E.A., F.T., Writing: B.A., E.A., F.T.

Conflict of Interest: No conflict of interest was declared by the authors.

Financial Disclosure: The authors declared that this study received no financial support.

\section{References}

1. Cheatham SW, Kolber MJ, Salamh PA. Meralgia paresthetica: A review of the literature. Int J Sports Phys Ther 2013;8:883-893.

2. Van Slobbe AM, Bohnen AM, Bernsen RM, Koes BW, Bierma-Zeinstra SM. Incidence rates and determinants in meralgia paresthetica in general practice. J Neurol 2004;251:294-297.

3. Parisi TJ, Mandrekar J, Dyck PJ, Klein CJ. Meralgia paresthetica: relation to obesity, advanced age, and diabetes mellitus. Neurology 2011;77:15381542 .

4. Bodner G, Bernathova M, Galiano K, Putz D, Martinoli C, Felfernig M. US of the lateral femoral cutaneous nerve: normal findings in a cadaver and in volunteers. Reg Anesth Pain Med 2009;34:265-268.

5. Hospodar PP, Ashman ES, Traub JA. Anatomic study of the lateral femoral cutaneous nerve with respect to the ilioinguinal surgical dissection. J Orthop Trauma 1999;13:207-211.

6. Grothaus MC, Holt M, Mekhail AO, Ebraheim NA, Yeasting RA. Lateral femoral cutaneous nerve: an anatomic study. Clin Orthop Relat Res 2005;437:164-168.

7. Beltran LS, Bencardino J, Ghazikhanian V, Beltran J. Entrapment neuropathies, 3: Lower limb. Semin Musculoskelet Radiol 2010;14:501-511.

8. Ozçakar L, Carli AB, Tok F, et al. The utility of musculoskeletal ultrasound in rehabilitation settings. Am J Phys Med Rehabil 2013;92:805-817.

9. ShannonJ, Lang SA, Yip RW, Gerard M. Lateral femoral cutaneous nerve block revisited: a nerve stimulator technique. Reg Anesth 1195;20:100-104.

10. Cook JL, Cook J. The lateral femoral cutaneous nerve block. Dermatol Surg 2000;26:81-83.

11. Özçakar L, Kara M, Chang KV, et al. Nineteen reasons why physiatrists should do musculoskeletal ultrasound: EURO-MUSCULUS/USPRM recommendations. Am J Phys Med Rehabil 2015;94:e45-49.

12. Kara M, Özçakar L, De Muynck M, Tok F, Vanderstraeten G. Musculoskeletal ultrasound for peripheral nerve lesions. Eur J Phys Rehabil Med 2012;48:665-674.

13. Ozçakar L, Tok F, De Muynck M, Vanderstraeten G. Musculoskeletal ultrasonography in physical and rehabilitation medicine. J Rehabil Med 2012; 44:310-318.

14. Ng I, Vaghadia H, Choi PT, Helmy N. Ultrasound imaging accurately identifies the lateral femoral cutaneous nerve. Anesth Analg 2008;107:10701074 .

15. Hurdle MF, Weingarten TN, Crisostomo RA, Psimos C, Smith J Ultrasound guided blockade of the lateral femoral cutaneous nerve: technical description and rewiev of 10 cases. Arch Phys med Rehabil 2007;88:1362-1324. 
16. Sharrock NE. Inadvertent "3-in-1-block"following injection of the lateral cutaneous nerve of the thigh. Anesth Analg 1980;59:887-888.

17. Shteynberg A, Riina LH, Glickman LT, Meringolo JN, Simpson RL. Ultrasound guided lateral femoral cutaneous nerve block: Safe and simple anesthesia for harvesting skin graft. Burns 2013;39:146-149.
18. Wardrop PJC, Nishikawa H. Lateral cutaneous nerve of the thigh blockade as primary anaesthesia for harvesting skin grafts. Br J Plast Surg 1995;48:597600.

19. Özçakar L, Onat ŞŞ, Gürçay E, Kara M. Are Blind Injections Ethical or Historical?: Think Twice with Ultrasound. Am J Phys Med Rehabil 2016;95:158-160. 